\title{
Neurobiology of inflammation-associated anorexia
}

\author{
Laurent Gautron ${ }^{1 *}$ and Sophie Layé ${ }^{2}$ \\ The University of Texas Southwestern Medical Center, Dallas, TX, USA \\ 2 Psychoneuroimmunologie, Nutrition et Génétique, Université de Bordeaux, Bordeaux, France
}

\author{
Edited by: \\ Lucile Capuron, University Victor \\ Segalen Bordeaux, France \\ Reviewed by: \\ Robert Dantzer, University of Illinois at \\ Urbana-Champaign, USA \\ Lori Asarian, Swiss Federal Institute of \\ Technology Zurich, Switzerland \\ Valeria Mondelli, King's College \\ London, UK \\ *Correspondence: \\ Laurent Gautron, Division of \\ Hypothalamic Research, Department \\ of Internal Medicine, The University of \\ Texas Southwestern Medical Center, \\ 5323 Harry Hines Boulevard, Dallas, TX \\ 75390-9077, USA \\ e-mail: laurent.gautron@ \\ UTSouthwestern.edu
}

Compelling data demonstrate that inflammation-associated anorexia directly results from the action of pro-inflammatory factors, primarily cytokines and prostaglandins $E 2$, on the nervous system. For instance, the aforementioned pro-inflammatory factors can stimulate the activity of peripheral sensory neurons, and induce their own de novo synthesis and release into the brain parenchyma and cerebrospinal fluid. Ultimately, it results in the mobilization of a specific neural circuit that shuts down appetite. The present article describes the different cell groups and neurotransmitters involved in inflammation-associated anorexia and examines how they interact with neural systems regulating feeding such as the melanocortin system. A better understanding of the neurobiological mechanisms underlying inflammation-associated anorexia will help to develop appetite stimulants for cancer and AIDS patients.

\section{Keywords: appetite, brain, cachexia, inflammation, interleukin-1, melanocortin}

\section{INTRODUCTION: WHEN INFLAMMATION SUPPRESSES APPETITE}

Inflammation-associated anorexia refers to the reduction of food intake observed during acute and chronic inflammatory states in both men and animals. It is well established that laboratory animals reduce their food intake in response to the peripheral administration of proinflammatory cytokines such as interleukin-1 1 (IL-1 $1 \beta$ ) or stimulants of the release of cytokines such as lipopolysaccharide (LPS). Notably, the administration of LPS reduces meals frequency, while that of IL$1 \beta$ reduces both meals frequency and size (Langhans et al., 1993). LPS and IL-1 $\beta$ also induce an aversion for a novel food or a sucrose solution (Tazi et al., 1988; Langhans et al., 1990; Weingarten et al., 1993; Bauer et al., 1995; Goehler et al., 1995), inhibit food-motivated behavior (Bret-Dibat et al., 1995; Kent et al., 1996), render the consumption of sucrose less pleasurable (anhedonia) (Yirmiya, 1996; Borowski et al., 1998; Merali et al., 2003), and increase the preference for carbohydrates and avoidance for aversive substances (Aubert et al., 1995; Cross-Mellor et al., 2004; Aubert and Dantzer, 2005). Although appetite (and thus anorexia) cannot be directly evaluated in animals, most researchers have been using the term of "anorexia" in animals based on the assumption that reduced appetite accounts for the reduction of food intake that follows the administration of either cytokines or LPS (Konsman and Dantzer, 2001). Inflammation-associated anorexia is acknowledged to help maintaining body integrity in face of infections and physical injuries (Hart, 1988; Exton, 1997). In essence, it is part of a process of energy repartition involving reducing activities such as food seeking and digestion which would otherwise consume up the energy needed to develop immune responses. There is also some evidence that food deprivation per se prolongs the survival of mice infected with Listeria (Wing and Young, 1980), a phenomenon that possibly involves the reduction of the levels of micronutrients required for bacterial proliferation (Weinberg, 1984).
Patients with chronic inflammation commonly complain about early satiety and loss of appetite, which in the case of cancerous and HIV-positive individuals can accompany dramatic weight loss known as cachexia (Laviano et al., 2003; Tisdale, 2009). The microenvironment surrounding tumoral cells, as well as tumoral cells themselves, are thought to produce pro-inflammatory cytokines (Seruga et al., 2008), and tumor-bearing rodents frequently show anorexia (Bernstein and Fenner, 1983; Bernstein et al., 1985; PlataSalaman et al., 1998; Meguid et al., 1999; Varma et al., 2001). It is important to mention that cachexia and anorexia are distinct phenomena which do not necessarily coexist (depending on tumor size and location, age); however, patients with both conditions show the worst prognosis (Laviano et al., 2003; Tisdale, 2009). Of note, the reduction of appetite observed in cancer patients does not solely result from inflammation but also from psychological distress and anticancer therapies (i.e., interferons) (Capuron et al., 2002). Unfortunately, efficient therapies to alleviate inflammationassociated anorexia are currently limited and, therefore, investigating their underlying mechanisms is truly relevant in the fight against cancer- and infection-related loss of appetite.

\section{HOW DO PRO-INFLAMMATORY CYTOKINES ALTER NEURAL ACTIVITY? \\ THE NEURAL PATHWAY}

Communication from the periphery to the brain involves, in addition to endocrine mechanisms, cranial and spinal nerves innervations. Virtually all tissues are innervated by a dense network of cranial and/or spinal sensory terminals which are capable of detecting a wide range of physiological signals. It has been shown that peripheral sensory neurons can sense pro-inflammatory factors. Receptors and binding sites for IL- $1 \beta$ and prostaglandin $\mathrm{E}_{2}$ (PGE2), for instance, have been reported in vagal, spinal, and trigeminal 
sensory neurons (Matsumura et al., 1995; Goehler et al., 1997; Ek et al., 1998; Copray et al., 2001; Obreja et al., 2002; Patwardhan et al., 2008). Furthermore, electrophysiological studies demonstrated that both IL-1 $\beta$ and PGE2 rapidly depolarize vagal sensory neurons (Niijima, 1996; Gaige et al., 2004; Snitsarev et al., 2007), as well as trigeminal and spinal sensory neurons (Pitchford and Levine, 1991; England et al., 1996; Binshtok et al., 2008; Takeda et al., 2008).

It is widely agreed that the action of pro-inflammatory factors on peripheral sensory terminals plays a prominent role when an inflammatory event is confined to a specific tissue. For example, trigeminal afferents that innervate the meninges are recruited upon inflammation limited to the intracranial cavity (i.e., meningitis, migraine), and the application of a mixture of pro-inflammatory agents on meninges sensory terminals induces profound feeding suppression in rats (Malick et al., 2001). More direct evidence of the involvement of the neural pathway in anorexia has been provided by experiments conducted in vagotomized animals. Rodents with bilateral subdiaphragmatic surgical vagotomy or chemical deafferentation (capsaicin) show attenuated anorexia and brain IL-1 $\beta$ expression in response to the intraperitoneal administration of LPS or IL-1ß (Bret-Dibat et al., 1995; Laye et al., 1995; Sergeev and Akmaev, 2000) and are less sensitive to the aversive effects of peripheral IL-1 $\beta$ (Goehler et al., 1995). Likewise, vagotomy procedures attenuate anorexia in tumor-bearing rats (Bernstein, 1996).

The nucleus of the solitary tract (NTS) and the adjacent area postrema (AP) located in the dorso-caudal brainstem are the primary relays of vagal terminal fields in the central nervous system (Figure 1). The NTS also receives indirect projections from some trigeminal and spinal sensory neurons (Gamboa-Esteves et al., 2001; Craig, 2002; Burstein and Jakubowski, 2005). Glutamate serves as the main neurotransmitter in vagal afferents terminals in the NTS, and it has been shown that LPS administration induces glutamate release in the NTS (Lin et al., 1999). In fact, one study has shown that the peripheral administration of metabotropic glutamate receptor antagonists attenuates inflammation-associated anorexia (Weiland et al., 2006), an effect that could possibly be explained by a reduction of vagal and/or spinal glutamatergic neurotransmission. The implication of the NTS in immune sensing is also demonstrated by neuroanatomical studies using the expression of $c$-fos as a marker of neuronal activation. Multiple investigators have reported robust $c$-fos expression in the NTS subsequently to an intraperitoneal inflammation (Wan et al., 1993; Rivest and Laflamme, 1995; Sagar et al., 1995; Konsman et al., 2000; Ge et al., 2001). Similarly, tumor-bearing rats show $c$-fos expression in the NTS (Konsman and Blomqvist, 2005; Ruud and Blomqvist, 2007).

\section{THE HUMORAL PATHWAY}

In contrast with previously mentioned observations, several studies showed the intact anorectic effects of LPS and IL- $1 \beta$ in vagotomized animals (Schwartz et al., 1997; Porter et al., 1998; Wieczorek et al., 2005). The induction of $c$-fos in the NTS following either intravenous LPS or IL- $1 \beta$ is also preserved in vagotomized animals (Ericsson et al., 1997; Hermann et al., 2001), suggesting that an intact vagus nerve is not always required for the stimulation of NTS neurons in response to an immune challenge. Another mechanism by which pro-inflammatory factors trigger anorexia involves their direct action on the central nervous system. For instance, the intracerebroventricular administration of a small dose of LPS or IL-1 $\beta$ is sufficient to induce anorexia (Kent et al., 1992; Yao et al., 1999). Other cytokines such as tumor necrosis factor alpha and interleukin- 6 similarly reduce feeding when centrally administered (Kapas and Krueger, 1992; Fantino and Wieteska, 1993; Plata-Salaman, 1996; Plata-Salaman et al., 1996; Sonti et al., 1996). IL-1 $\beta$ orchestrates the expression of other cytokines in the brain (Laye et al., 1994; Mingam et al., 2008a), and more importantly, the blockade of cerebral IL- $1 \beta$ receptor by its endogenous antagonist IL-1ra partially prevents LPS-induced anorexia (Laye et al., 2000). The action of pro-inflammatory cytokines directly on the central nervous system is referred in the literature to as "the humoral pathway" (Figure 1).

It initially seemed surprising that cytokines are capable of acting on the central nervous system when considering that the blood-brain barrier prevents most blood-borne pro-inflammatory factors and immune cells to access the brain. In fact, the central nervous system does contain immunocompetent cells which are fully capable of detecting pathogen-associated molecular patterns and of producing pro-inflammatory factors in response to injury and inflammatory challenges (Rivest, 2003). Furthermore, specialized areas of the brain known as circumventricular organs are devoid of a blood-brain barrier, and as such are readily accessible to systemic pathogen-associated molecular patterns such as LPS (Rivest, 2003). The mammalian brain contains four known circumventricular organs which are the AP, the median eminence, the subfornical organ, and the organum vasculosum of the lamina terminalis. Brain cells capable of producing IL- $1 \beta$ have been identified as perivascular macrophages, microglial cells and macrophages in the choroid plexus and meninges (van Dam et al., 1992, 1995; Buttini and Boddeke, 1995; Konsman et al., 1999; Goehler et al., 2006). Numerous studies have reported the presence of IL-1 binding sites and receptors (IL-1R) prominently in brain endothelial cells (Farrar et al., 1987; Takao et al., 1990; Ban et al., 1991; Cunningham et al., 1992; Ericsson et al., 1995; French et al., 1999; Konsman et al., 2004), choroid plexus, and to a lesser extent in some neurons of the hippocampus, arcuate nucleus and amygdala. Recently, Ching et al. (2007) elegantly demonstrated using a genetic approach that the selective deletion of IL-1R in brain endothelial cells prevents intravenous IL-1-induced fever and hypothalamo-pituitary-adrenal axis stimulation (this study, however, did not survey food intake). Another study showed that the pharmacological inhibition of nuclear factor kappa B (NF-kB), a transcription factor downstream of IL-1 signaling pathway in endothelial cells, attenuates IL-1-induced anorexia (Nadjar et al., 2005). Similarly, LPS-induced anorexia is blunted in mice lacking MyD88 (Myeloid differentiation primary response gene 88) (Wisse et al., 2007), which is a critical molecular component of both IL-1 and LPS signaling in perivascular and endothelial cells (Gosselin and Rivest, 2008).

All the aforementioned data demonstrate that LPS and IL-1 $\beta$ signaling in brain endothelial cells (and possibly perivascular cells) plays a critical role in inflammation-associated anorexia. However, these data do not explain how LPS or IL- $1 \beta$ ultimately change the activity of neurons involved in feeding. The production and release of PGE2 within the intracranial cavity is promoted by the 


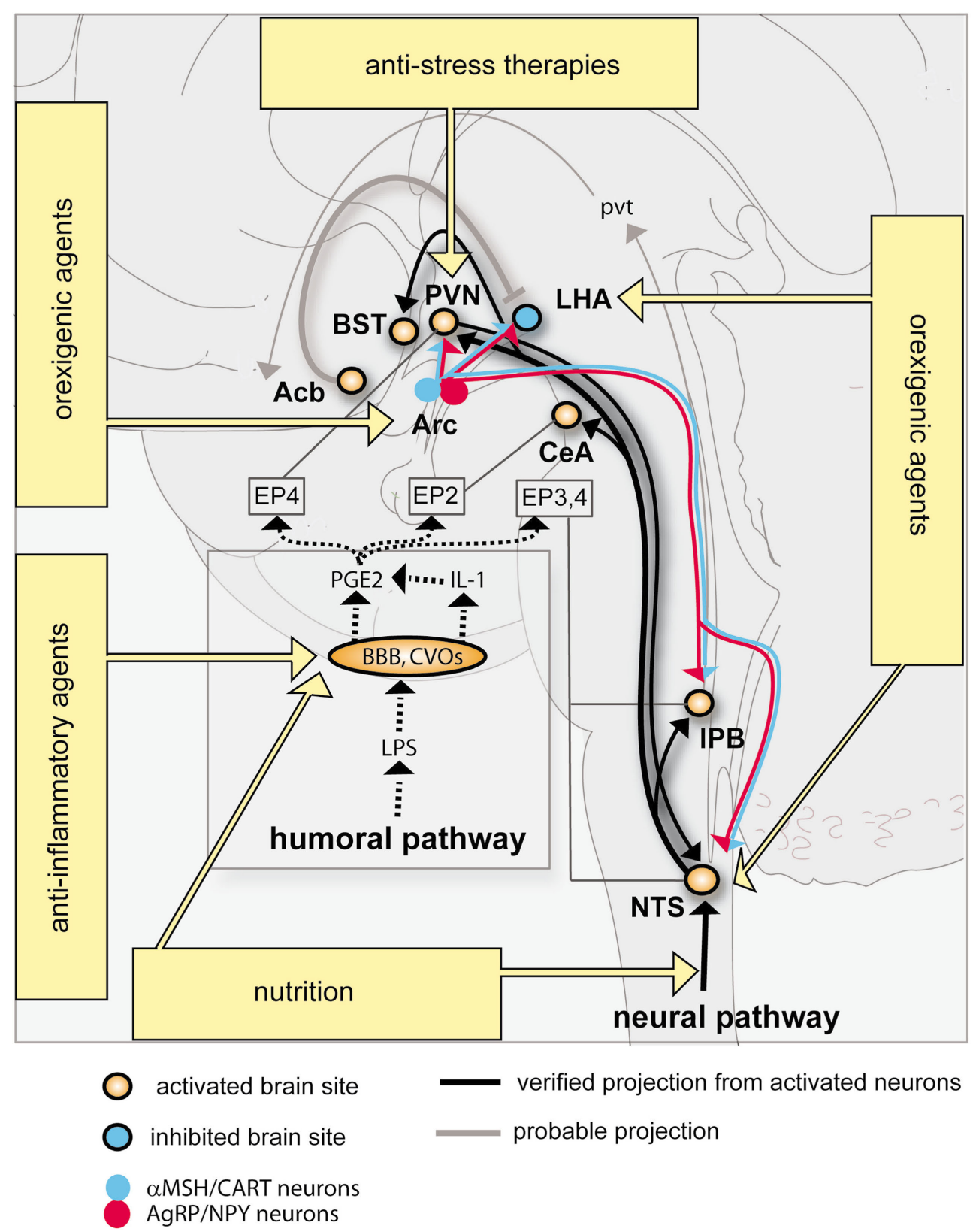

FIGURE 1 | Neural circuitry implicated in inflammation-associated anorexia and possible approaches to alleviate anorexia. The action of pro-inflammatory cytokines and pathogen-associated molecular patterns on peripheral sensory neurons (neural pathway) and the blood-brain barrier (humoral pathway) leads to changes in the activity of key feeding-related brain sites distributed in the brainstem and hypothalamus. This neurobiological model predicts that inflammation-associated anorexia can be modulated by several complementary approaches including to not limited to nutritional and pharmacological approaches. The most promising strategy to attenuate anorexia consists in modulating the melanocortin system by administrating orexigenic agents which are known to act on Arc neurons. Dotted lines represent the diffusion and action of factors implicated in the humoral pathway. EPs are connected to brain sites in which they are predominantly expressed. Abbreviations: Acb, rostral nucleus accumbens; Arc, arcuate nucleus; BBB, blood-brain barrier; BST, nucleus of the stria terminalis; $\mathrm{CeA}$, central amygdala; CVOs, circumventricular organs; EP, prostaglandins receptors; IL-1, interleukin-1; LHA, lateral hypothalamus; LPS, lipopolysaccharide; PGE2, prostaglandins E2; PVN, nucleus of the paraventricular hypothalamus; pvt, paraventricular thalamus; IPB, lateral parabrachial nucleus; NTS, nucleus of the solitary tract. stimulation of IL-1R and LPS receptor positioned in cells forming the blood-brain barrier including endothelial cells, choroid plexus and meninges (Rivest, 1999; Ek et al., 2001; Konsman et al., 2004). In turn, PGE2 are thought to directly act on neurons important in feeding. In agreement with such a view, the central administration of PGE2 induces $c$-fos expression in brain sites directly comparable to that recruited by IL-1 $\beta$ (Lacroix et al., 1996). Additionally, it has been consistently shown that the pharmacological inhibition and the genetic deletion of enzymes synthesizing PGE2 reduce anorexia following peripheral LPS or IL-1 $\beta$ (Johnson et al., 2002; Lugarini 
et al., 2002; Pecchi et al., 2006; Elander et al., 2007). According to the literature, PGE2 bind four known $G$ proteins-coupled receptors (EP1-4) which are abundantly expressed in the preoptic area, hypothalamus and hindbrain including the NTS (Zhang and Rivest, 1999; Oka et al., 2000; Engblom et al., 2001) (Figure 1). Also, EP3 has been recently implicated in the regulation of feeding since mice lacking this receptor develop hyperphagia (Sanchez-Alavez et al., 2007). Finally, there is direct evidence that PGE2 can modulate the electrophysiological activity of PGE2-sensitive neurons in brain regions important in feeding such as the NTS. For example, the application of PGE2 in NTS preparation rapidly enhances glutamatergic transmission, while it reduces presynaptic vagal neurotransmission (Marty et al., 2008).

\section{THE NEURAL CIRCUITS PRODUCING INFLAMMATORY- ASSOCIATED ANOREXIA VISCERO-SENSORY PATHWAYS}

The regulation of appetite involves multiple internal and environmental factors which are integrated in specific neuronal groups distributed across the neuraxis. The brainstem contributes to the short-term regulation of appetite in response to signals arising from the gut. Notably, early studies in decerebrate animals demonstrated that the brainstem is sufficient to produce post-prandial satiety (Grill and Smith, 1988). Within the brainstem, the NTS plays an important role in the control of satiety and aversion by acting as viscero-sensory relays for gastrointestinal signals predominantly conveyed through the vagus nerve (Adachi et al., 1991; Schwartz, 2000). As mentioned earlier, NTS neurons integrate signals originating from both the neural and humoral pathways (Figure 1), making this brain structure one of the most important site in mediating inflammation-associated anorexia. The administration of IL-1 into the fourth ventricle, which provides cerebrospinal fluid to the brainstem, is sufficient to induce $c$-fos in NTS and, more importantly, a profound anorexia (DeBoer et al., 2009). Among NTS neurons known to be activated in response to LPS are neurons producing glucagon-like peptide 1 (GLP-1) (Rinaman, 1999), a well-known anorectic peptide (Kinzig et al., 2002). Specifically, the pharmacological inhibition of GLP-1 receptor in the brainstem attenuates LPS-induced anorexia, suggesting that GLP-1-producing neurons directly contribute to anorexia (Grill et al., 2004).

NTS neurons activated in response to inflammation send projections to the lateral parabrachial nucleus (IPB), bed nucleus of the stria terminalis (BST), central amygdala (CeA) and paraventricular nucleus of the hypothalamus (PVN) (Ericsson et al., 1994; Tkacs and Li, 1999; Buller and Day, 2002; Crane et al., 2003; Gaykema et al., 2007) (Figure 1). The exact role of the aforementioned structures in feeding behavior remains understudied, however, it is known that these structures all receive visceral- and gustatory-related information and are, individually or collectively, implicated in hypophagic behaviors such as stress-induced anorexia (Koob, 1999), satiety/aversion (Reilly and Trifunovic, 2000; Sclafani et al., 2001; Ferreira et al., 2006; Becskei et al., 2007), food avoidance and preference (Kelley et al., 2003; Ferreira et al., 2006). Yet the direct implication of these structures in anorexia will require further testing.

The PVN deserves a special mention. Indeed, lesions of the PVN increase food intake (Gold, 1970; Choi and Dallman, 1999), indicating the pivotal role of this structure in reducing feeding.
In addition, we previously showed that the expression of $c$-fos in the PVN positively correlates with the intensity of anorexia after LPS administration (Gautron et al., 2005). While it is admitted that corticotropin-releasing hormone $(\mathrm{CRH})$-producing neurons of the PVN control the hypothalamo-pituitary-adrenal axis, they are also good candidates to contribute to the anorectic effect of inflammation in view of the facts that $\mathrm{CRH}$ exerts anorectic effects (Dunn and Berridge, 1990) and the immunoneutralization of CRH attenuates IL-1-induced anorexia (Uehara et al., 1989). However, CRH is produced in widespread brain sites and the contribution of PVN CRH-expressing neurons in anorexia relative to other sites has not been verified. Cocaine- and amphetamineregulated transcript (CART) is another anorectic peptide produced in the PVN (Kristensen et al., 1998). Interestingly enough, CART-expressing neurons of the PVN are activated in response to LPS (Fuzesi et al., 2008), number of which also innervate the NTS. Together, it indicates that inflammation-associated anorexia presumably engages reciprocally connected neuronal groups in the NTS and PVN (Figure 1).

\section{THE MELANOCORTIN SYSTEM}

The melanocortin system tightly regulates appetite downstream of hormonal indicators of energy status such as leptin, insulin and ghrelin. The arcuate nucleus of the hypothalamus (Arc) contains pro-opiomelanocortin neurons (POMC) which produce the anorectic peptides alpha-melanocyte stimulating hormone $(\alpha-\mathrm{MSH})$ and CART. Importantly, $\alpha-\mathrm{MSH}$ is an endogenous agonist of the melanocortin-4 receptor (MC4R) which is a major regulator of food intake (Seeley et al., 2004; Cone, 2006). Uniquely, the Arc also contains neurons which produce the orexigenic peptides agouti-related protein (AgRP) and neuropeptide Y (NPY). AgRP is an endogenous MC4R antagonist. Persuasive evidence has established that the activity of both populations of neurons is oppositely regulated by the humoral signals leptin and ghrelin (Seeley et al., 2004). In fact, whereas leptin signaling in POMC neurons mediates its anorectic effects (Hill et al., 2008), ghrelin signaling in AgRP neurons promotes its stimulatory effects on appetite (Luquet et al., 2007). Ultimately, these neurons project to a number of brain sites involved in feeding including the NTS, PVN, lateral hypothalamus and IPB to modulate their activity in face of changes in energy status (Figure 1).

Earlier studies reported increased plasma leptin levels in response to LPS in mice and rats (Sarraf et al., 1997; Faggioni et al., 1999; Finck and Johnson, 1999; Mastronardi et al., 2000), making leptin a potential candidate involved in inflammationassociated anorexia. Moreover, the melanocortin system has been shown to be involved in acute and chronic inflammatoryassociated anorexia based on neuroanatomical (Sergeyev et al., 2001; Reyes and Sawchenko, 2002; Borges et al., 2007; Scarlett et al., 2007), pharmacological (Huang et al., 1999; Wisse et al., 2001), electrophysiological (Scarlett et al., 2007), and transgenic mice studies (Marks et al., 2001). However, parallel studies have challenged the role played by leptin and the melanocortin system in anorexia by showing that intraperitoneal LPS does not elevate plasma leptin levels in rats (Giovambattista et al., 2000; Gautron et al., 2005; Spencer et al., 2007). In addition, leptinand leptin receptor-deficient animals are still fully responsive 
to the anorectic effects of LPS (Faggioni et al., 1997; Lugarini et al., 2005). One of our studies also failed to observe increased $c$-fos expression in POMC neurons in response to LPS (Gautron et al., 2005). Likewise, no significant variation of expression for NPY, AgRP or POMC mRNA in the Arc of LPS-treated rodents using RNase protection assay or in situ hybridization were found (Turrin et al., 2001; Johnson et al., 2002; Gautron et al., 2005). Finally, Reyes and Sawchenko (Reyes and Sawchenko, 2002) demonstrated that IL-1-induced anorexia was not prevented by chemical lesion of the Arc or the physical disruption of its projections.

If previous studies have not firmly established the role played by the melanocortin system in triggering anorexia during inflammation, nevertheless they have suggested its modulatory role. For example, a recent study has evidenced that the immunoneutralization of leptin attenuates LPS-induced anorexia in rats at 8 and $24 \mathrm{~h}$ after LPS (Sachot et al., 2004). This observation agrees with studies showing that inflammatory anorexia due to LPS or turpentine is lowered whenever leptin falls, i.e., after food restriction (Lennie, 1998; Gautron et al., 2005).

\section{HEDONIC PATHWAYS}

The regulation of the hedonic aspects of food intake (i.e., palatability, reward) primarily involves the lateral hypothalamus and connected brain sites such as the nucleus accumbens and ventral tegmental area. The lateral hypothalamus uniquely contains a population of neurons expressing the neuropeptides orexins (Sakurai et al., 1998) which are well established to control arousal and stimulate feeding (Mieda et al., 2004). As expected, fasting is associated with increased $c$-fos in orexins neurons as well as up-regulated prepro-orexin mRNA expression (Sakurai et al., 1998). One early study demonstrated that peripheral LPS reduces lateral hypothalamus auto-stimulation in rats (Borowski et al., 1998), suggesting that inflammation results in the inhibition of this brain site. In agreement with such a view, we demonstrated that LPS suppressed $c$-fos expression in the lateral hypothalamus of fasted rats (Gautron et al., 2005). The previous study was followed by other works showing that LPS specifically reduces $c$-fos expression in orexins neurons (Becskei et al., 2008; Park et al., 2008; Gaykema and Goehler, 2009). The inhibition of orexins neurons in response to LPS is concomitant to the activation of nucleus accumbens neurons (Park et al., 2008), and it has been previously proposed that gabaergic neurons located in the rostral nucleus accumbens produces anhedonia and reduction in motivated feeding by inhibiting orexins neurons (Kelley, 1999). It is therefore likely that the aforementioned circuitry is involved in LPS-induced anhedonia.

\section{HOW TO STIMULATE APPETITE IN CHRONIC DISEASES? ANTI-INFLAMMATORY APPROACHES}

Many promising pharmacological agents have been clinically tested but, unfortunately, failed to demonstrate therapeutic efficacy against anorexia or cachexia. Among other examples, endocannabinoids showed limited effects in AIDS patients (Beal and Flynn, 1995) and no greater effect over placebo in advanced cancer patients (Strasser et al., 2006). Pharmacological agents currently in use to combat anorexia are thalidomide, eicosapentaenoic acid (a long chain $\omega-3$ polyunsaturated fatty acid), corticosteroids and progestrogens derivates (Mattox, 2005; Tisdale, 2006). Despite the fact they exert well documented anti-inflammatory actions, these agents show only temporary benefits on appetite, numerous side effects and their mechanism of actions on feeding remain unclear.

Nutritional approaches are not only necessary to prevent deficiencies and reduce gastrointestinal upsets, but also to increase the survival time of cancer patients by reducing whole body inflammation. For instance, a low fat and high fibers diet has been shown to prolong the survival of women with breast cancer (Zhang et al., 1995; Pierce et al., 2007). Some studies also suggested that rats fed on fish oil (rich in long chain $\omega-3$ polyunsaturated fatty acid) show reduced anorexia in response to IL-1 and tumor growth (Hellerstein et al., 1989; Goncalves et al., 2006). In addition, the use of non-steroidal anti-inflammatory drugs combined with a diet enriched in $\omega$-3 can modestly improve appetite in cancer patients (Lundholm et al., 1994; Wigmore et al., 2000; Cerchietti et al., 2004; Jatoi et al., 2004). By contrast, other studies have failed to demonstrate any beneficial effects of $\omega$-3-enriched diets in LPS-treated mice and cancerous patients (Mingam et al., 2008b; Mazzotta and Jeney, 2009). Despite these contradictory results, considering the key role played by PGE2 in immune-to-brain communication, therapeutic trials involving the manipulation of eicosanoids metabolism by pharmacological and nutritional means is considered a useful strategy to lower anorexia (Figure 1).

Once again, appetite is regulated both by internal and environmental factors. Cancer patients are submitted to intense stress, and efforts to attenuate anorexia using anti-inflammatory agents and nutrition may be in vain if their psychological distress is not addressed. In this regard, attention to the patient's psychological well-being has been shown to help patients regaining interest for food (Holland et al., 1977). Presumably, one mechanism by which stress reduces appetite is by directly interfering with neural systems involved in feeding including POMC and CRH neurons (Koob, 1999; Liu et al., 2007); another mechanism is by aggravating peripheral inflammation (Gibb et al., 2008).

\section{BLOCKING THE NEURAL PATHWAY}

Agents that reduce the activity of vagal and/or spinal nerves such as anti-emetics and analgesics can also be used to treat cancer patients (Davis et al., 2006). While it is unclear whether sensory afferents can directly detect tumors, it has been proposed that reducing the activity of peripheral sensory afferents may result in augmented appetite in cancer. For example, the blockade of type 3 serotonergic receptors (5-HT3R) improves the ability of cancer patients to enjoy food (Edelman et al., 1999). Binding sites for 5-HT3R are abundant in the NTS/AP (Marazziti et al., 2001), but the receptor mRNA itself is found in the nodose ganglion and not the NTS/AP (Tecott et al., 1993; Morales and Wang, 2002). Thus, 5-HT3R ligands act on receptors produced by vagal neurons and transported to their terminals located within the NTS and AP. These treatments in combination with adequate nutrition are useful to alleviate nausea, pain and gastrointestinal tract discomfort but they do not directly address the problem of loss of appetite. Perhaps, utilizing drugs that target NTS neurotransmitters could 
be useful. For example, exendin-(9-39) which is an antagonist of GLP-1 receptor has been shown to attenuate LPS-induced anorexia in rats (Grill et al., 2004).

\section{STIMULATING OREXIGENIC PATHWAYS}

A neurobiological roadmap of the mechanisms underlying anorexia is now available and, to effectively alleviate anorexia, it would be preferable to target neural circuits well known to be involved in the control of feeding. Thus far, the most promising strategy to attenuate anorexia consists in modulating the melanocortin system by adjusting the circulating levels of endogenous or exogenous factors which are known to act on Arc neurons (Figure 1). We previously mentioned that the immunoneutralization of leptin, for instance, efficiently attenuates LPS-induced anorexia in rats (Sachot et al., 2004). Conversely, the administration of ghrelin, which stimulates NPY neurons, has given encouraging results in cancer patients (Neary et al., 2004; Wynne et al., 2005). The melanocortin system is not only regulated by hormones but also regulated by endogenous neurotransmitters. The stimulation of the serotonin receptor $2 \mathrm{C}$ (5-HT2CR) in POMC neurons reduces feeding (Xu et al., 2008). While increased serotonergic neurotransmission is observed in LPS-treated animals (Dunn, 1992; MohanKumar et al., 1999; Nolan et al., 2000), interestingly, 5-HT2CR antagonists administration attenuates peripheral and central LPS-induced anorexia (von

\section{REFERENCES}

Adachi, A., Kobashi, M., Miyoshi, N., and Tsukamoto, G. (1991). Chemosensitive neurons in the area postrema of the rat and their possible functions. Brain Res. Bull. 26, 137-140.

Asarian, L., Kopf, B. S., Geary, N., and Langhans, W. (2007).Pharmacological, but not genetic, disruptions in 5-HT(2C) receptor function attenuate LPS anorexia in mice. Pharmacol. Biochem. Behav. 86, 493-498.

Aubert, A., and Dantzer, R. (2005). The taste of sickness: lipopolysaccharideinduced finickiness in rats. Physiol. Behav. 84, 437-444.

Aubert, A., Goodall, G., and Dantzer, R. (1995). Compared effects of cold ambient temperature and cytokines on macronutrient intake in rats. Physiol. Behav. 57, 869-873.

Ban, E., Milon, G., Prudhomme, N., Fillion, G., and Haour, F. (1991). Receptors for interleukin-1 (alpha and beta) in mouse brain: mapping and neuronal localization in hippocampus. Neuroscience 43, 21-30.

Bauer, C., Weingarten, S., Senn, M., and Langhans, W. (1995). Limited importance of a learned aversion in the hypophagic effect of interleukin1 beta. Physiol. Behav. 57, 1145-1153.

Beal, J., and Flynn, N. (1995). AIDS-associated anorexia.J. Physicians Assoc. AIDS Care 2, 19-22.

Becskei, C., Grabler, V., Edwards, G. L., Riediger, T., and Lutz, T. A. (2007). Lesion of the lateral parabrachial nucleus attenuates the anorectic effect of peripheral amylin and CCK. Brain Res. 1162, 76-84.

Becskei, C., Riediger, T., Hernadfalvy, N., Arsenijevic, D., Lutz, T. A., and Langhans, W. (2008). Inhibitory effects of lipopolysaccharide on hypothalamic nuclei implicated in the control of food intake. Brain Behav. Immun. 22, 56-64.

Bernstein, I. L. (1996). Neutral mediation of food aversions and anorexia induced by tumor necrosis factor and tumors. Neurosci. Biobehav. Rev. 20, 177-181.

Bernstein, I. L., and Fenner, D. P. (1983). Learned food aversions: heterogeneity of animal models of tumor-induced anorexia. Appetite 4, 79-86.

Bernstein, I. L., Treneer, C. M., Goehler, L. E., and Murowchick, E. (1985). Tumor growth in rats: conditioned suppression of food intake and preference. Behav. Neurosci. 99, 818-830.

Binshtok, A. M., Wang, H., Zimmermann, K., Amaya, F., Vardeh, D., Shi, L., Brenner, G. J., Ji, R. R., Bean, B. P., Woolf, C. J., and Samad, T. A. (2008). Nociceptors are interleukin-1beta sensors. J. Neurosci. 28, 14062-14073.

Blackhall, L., Petroni, G., Shu, J., Baum, L., and Farace, E. (2009). A pilot study evaluating the safety and efficacy of modafinil for cancer-related fatigue. J. Palliat. Med. 12, 433-439.

Borges, B. C., Antunes-Rodrigues, J., Castro, M., Bittencourt, J. C., Elias, C. F., and Elias, L. L. (2007). Expression of

Meyenburg et al., 2003a,b; Asarian et al., 2007). Together, it suggests that modulating the signaling pathways of various hormones and neurotransmitters acting on Arc neurons can reduce anorexia.

Recent studies have shown that orexins neurons are inhibited in response to peripheral inflammation (Gaykema and Goehler, 2009), which is a remarkable observation given the role of the lateral hypothalamus in regulating hedonic processes and the fact that cancer and AIDS patients often show anhedonia. Modafinil, a psychostimulant which stimulates orexin neurons (Scammell et al., 2000), has already been shown to diminish fatigue and improve quality of life in cancer patients (Blackhall et al., 2009; Spathis et al., 2009). It would be interesting to further test the ability of this drug along with compounds that target specifically the orexinergic system to reduce anorexia and anhedonia.

In conclusion, multiple factors and neural systems contribute to inflammation-associated anorexia and no single intervention will suffice in order to reverse the neurochemical changes responsible for anorexia in cancer and AIDS patients. Moreover, targeting the central nervous system is always complicated because of the blood-brain barrier and the lack of specificity of many available pharmacological agents. Nevertheless, the research on feeding behavior is permanently evolving, and new neural mechanisms are being regularly discovered, giving researchers opportunities to evaluate new therapeutics.

hypothalamic neuropeptides and the desensitization of pituitary-adrenal axis and hypophagia in the endotoxin tolerance. Horm. Behav. 52, 508-519.

Borowski, T., Kokkinidis, L., Merali, Z., and Anisman, H. (1998). Lipopolysaccharide, central in vivo biogenic amine variations, and anhedonia. Neuroreport 9, 3797-3802.

Bret-Dibat, J. L., Bluthe, R. M., Kent, S. Kelley, K. W., and Dantzer, R. (1995). Lipopolysaccharide and interleukin-1 depress food-motivated behavior in mice by a vagal-mediated mechanism. Brain Behav. Immun. 9, 242-246.

Buller, K. M., and Day, T. A. (2002). Systemic administration of interleukin-1beta activates select populations of central amygdala afferents. $J$. Comp. Neurol. 452, 288-296.

Burstein, R., and Jakubowski, M. (2005) Unitary hypothesis for multiple triggers of the pain and strain of migraine. J. Comp. Neurol. 493, 9-14.

Buttini, M., and Boddeke, H. (1995). Peripheral lipopolysaccharide stimulation induces interleukin-1 beta messenger RNA in rat brain microglial cells. Neuroscience 65, 523-530.

Capuron, L., Gumnick, J. F., Musselman, D. L., Lawson, D. H., Reemsnyder, A., Nemeroff, C. B., and Miller, A. H. (2002). Neurobehavioral effects of interferon-alpha in cancer patients: phenomenology and paroxetine responsiveness of symptom dimensions. Neuropsychopharmacology 26, 643-652.
Cerchietti, L. C., Navigante, A. H., Peluffo, G. D., Diament, M. J., Stillitani, I., Klein, S.A., and Cabalar, M.E. (2004). Effects of celecoxib, medroxyprogesterone, and dietary intervention on systemic syndromes in patients with advanced lung adenocarcinoma: a pilot study. J. Pain Symptom Manage. 27, 85-95.

Ching, S., Zhang, H., Belevych, N., He, L., Lai, W., Pu, X. A., Jaeger, L. B., Chen, Q., and Quan, N. (2007). Endothelialspecific knockdown of interleukin-1 (IL-1) type 1 receptor differentially alters CNS responses to IL-1 depending on its route of administration. J. Neurosci. 27, 10476-10486.

Choi, S., and Dallman, M. F. (1999). Hypothalamic obesity: multiple routes mediated by loss of function in medial cell groups. Endocrinology 140, 4081-4088.

Cone, R. D. (2006). Studies on the physiological functions of the melanocortin system. Endocr. Rev. 27, 736-749.

Copray, J. C., Mantingh, I., Brouwer, N., Biber, K., Kust, B. M., Liem, R. S., Huitinga, I., Tilders, F. J., van Dam, A. M., and Boddeke, H. W. (2001). Expression of interleukin-1 beta in rat dorsal root ganglia. J. Neuroimmunol. 118, 203-211.

Craig, A. D. (2002). How do you feel? Interoception: the sense of the physiological condition of the body. Nat. Rev. Neurosci. 3, 655-666.

Crane, J. W., Buller, K. M., and Day, T. A. (2003). Evidence that the bed nucleus 
of the stria terminalis contributes to the modulation of hypophysiotropic corticotropin-releasing factor cell responses to systemic interleukin-1beta. J. Comp. Neurol. $467,232-242$.

Cross-Mellor, S. K., Kavaliers, M., and Ossenkopp, K. P. (2004). Comparing immuneactivation (lipopolysaccharide) and toxin (lithium chloride)-induced gustatory conditioning: lipopolysaccharide produces conditioned taste avoidance but not aversion. Behav. Brain Res. $148,11-19$

Cunningham, E. T. Jr., Wada, E., Carter, D. B., Tracey, D. E., Battey, J. F., and De Souza, E. B. (1992). In situ histochemical localization of type I interleukin-1 receptor messenger RNA in the central nervous system, pituitary, and adrenal gland of the mouse. J. Neurosci. 12, 1101-1114.

Davis, M. P., Walsh, D., Lagman, R., and Yavuzsen, T. (2006). Early satiety in cancer patients: a common and important but underrecognized symptom. Support. Care Cancer 14, 693-698.

DeBoer, M. D., Scarlett, J. M., Levasseur, P. R., Grant, W. F., and Marks, D. L. (2009). Administration of IL-1beta to the 4 th ventricle causes anorexia that is blocked by agouti-related peptide and that coincides with activation of tyrosine-hydroxylase neurons in the nucleus of the solitary tract. Peptides $30,210-218$.

Dunn, A. J. (1992). Endotoxin-induced activation of cerebral catecholamine and serotonin metabolism: comparison with interleukin-1. J. Pharmacol. Exp. Ther. 261, 964-969.

Dunn, A. J., and Berridge, C. W. (1990). Physiological and behavioral responses to corticotropin-releasing factor administration: is CRF a mediator of anxiety or stress responses? Brain Res. Brain Res. Rev. 15, 71-100.

Edelman, M. J., Gandara, D. R., Meyers, F. J., Ishii, R., O'Mahony, M., Uhrich, M., Lauder, I., Houston, J., and Gietzen, D. W. (1999). Serotonergic blockade in the treatment of the cancer anorexia-cachexia syndrome. Cancer 86 , 684-688.

Ek, M., Engblom, D., Saha, S., Blomqvist, A., Jakobsson, P. J., and EricssonDahlstrand, A. (2001). Inflammatory response: pathway across the bloodbrain barrier. Nature 410, 430-431.

Ek, M., Kurosawa, M., Lundeberg, T., and Ericsson, A. (1998). Activation of vagal afferents after intravenous injection of interleukin-1beta: role of endogenous prostaglandins. J. Neurosci. 18, 9471-9479.

Elander, L., Engstrom, L., Hallbeck, M., and Blomqvist, A. (2007). IL-1beta and LPS induce anorexia by distinct mechanisms differentially dependent on microsomal prostaglandin $\mathrm{E}$ synthase-1. Am. J. Physiol. Regul. Integr. Comp. Physiol. 292, R258-R267.

Engblom,D., Ek,M., Ericsson-Dahlstrand, A., and Blomqvist,A. (2001).Activation of prostanoid $\mathrm{EP}(3)$ and $\mathrm{EP}(4)$ receptor mRNA-expressing neurons in the rat parabrachial nucleus by intravenous injection of bacterial wall lipopolysaccharide. J. Comp. Neurol. 440, 378-386.

England, S., Bevan, S., and Docherty, R. J. (1996). PGE2 modulates the tetrodotoxin-resistant sodium current in neonatal rat dorsal root ganglion neurones via the cyclic AMP-protein kinase A cascade. J. Physiol. 495(Pt. 2), 429-440.

Ericsson, A., Arias, C., and Sawchenko, P. E. (1997). Evidence for an intramedullary prostaglandin-dependent mechanism in the activation of the stress-related neuroendocrine circuitry by interleukin-1. J. Neurosci. 17, 7166-7179.

Ericsson, A., Kovacs, K. J., and Sawchenko, P. E. (1994). A functional anatomical analysis of central pathways subserving the effects of interleukin-1 on stress-related neuroendocrine neurons. J. Neurosci. 14, 897-913.

Ericsson, A., Liu, C., Hart, R. P., and Sawchenko, P. E. (1995). Type 1 interleukin-1 receptor in the rat brain: distribution, regulation, and relationship to sites of IL-1-induced cellular activation. J. Comp. Neurol. 361, 681-698.

Exton, M. S. (1997). Infection-induced anorexia: active host defence strategy. Appetite 29, 369-383.

Faggioni, R., Fantuzzi, G., Gabay, C., Moser, A., Dinarello, C. A., Feingold, K. R., and Grunfeld, C. (1999). Leptin deficiency enhances sensitivity to endotoxin-induced lethality. Am. J. Physiol. 276, R136-R142.

Faggioni, R., Fuller, J., Moser, A., Feingold, K. R., and Grunfeld, C. (1997). LPSinduced anorexia in leptin-deficient (ob/ob) and leptin receptor-deficient (db/db) mice. Am. J. Physiol. 273, R181-R186.

Fantino, M., and Wieteska, L. (1993). Evidence for a direct central anorectic effect of tumor-necrosis-factoralpha in the rat. Physiol. Behav. 53, 477-483.

Farrar, W. L., Kilian, P. L., Ruff, M. R. Hill, J. M., and Pert, C. B. (1987) Visualization and characterization of interleukin 1 receptors in brain. $J$. Immunol. 139, 459-463.

Ferreira, G., Ferry, B., Meurisse, M., and Levy, F. (2006). Forebrain structures specifically activated by conditioned taste aversion. Behav. Neurosci. 120, 952-962.
Finck, B. N., and Johnson, R. W. (1999). Intracerebroventricular injection of lipopolysaccharide increases plasma leptin levels. Neuroreport 10 , 153-156.

French, R. A., VanHoy, R. W., Chizzonite, R., Zachary, J. F., Dantzer, R., Parnet, P., Bluthe, R. M., and Kelley, K. W. (1999). Expression and localization of p80 and p68 interleukin-1 receptor proteins in the brain of adult mice. J. Neuroimmunol. 93, 194-202.

Fuzesi, T., Sanchez, E., Wittmann, G., Singru, P. S., Fekete, C., and Lechan, R. M. (2008). Regulation of cocaineand amphetamine-regulated transcript-synthesising neurons of the hypothalamic paraventricular nucleus by endotoxin; implication for lipopolysaccharide-induced regulation of energy homeostasis. $J$. Neuroendocrinol. 20, 1058-1066.

Gaige, S., Abou, E., Abysique, A., and Bouvier, M. (2004). Effects of interactions between interleukin-1 beta and leptin on cat intestinal vagal mechanoreceptors. J. Physiol. 555 , 297-310.

Gamboa-Esteves, F. O., Kaye, J. C., McWilliam, P. N., Lima, D., and Batten, T. F. (2001). Immunohistochemical profiles of spinal lamina I neurones retrogradely labelled from the nucleus tractus solitarii in rat suggest excitatory projections. Neuroscience 104, 523-538.

Gautron, L., Mingam, R., Moranis, A. Combe, C., and Laye, S. (2005). Influence of feeding status on neuronal activity in the hypothalamus during lipopolysaccharide-induced anorexia in rats. Neuroscience 134 933-946.

Gaykema, R. P., Chen, C. C., and Goehler L.E. (2007). Organization of immuneresponsive medullary projections to the bed nucleus of the stria terminalis, central amygdala, and paraventricular nucleus of the hypothalamus: evidence for parallel viscerosensory pathways in the rat brain. Brain Res. $1130,130-145$.

Gaykema, R. P., and Goehler, L. E. (2009) Lipopolysaccharide challenge-induced suppression of Fos in hypothalamic orexin neurons: their potential role in sickness behavior. Brain Behav Immun. 23, 926-930.

Ge, X., Yang, Z., Duan, L., and Rao, Z. (2001). Evidence for involvement of the neural pathway containing the peripheral vagus nerve, medullary visceral zone and central amygdaloid nucleus in neuroimmunomodulation. Brain Res. 914, 149-158.

Gibb, J., Hayley, S., Gandhi, R., Poulter, M. O., and Anisman, H. (2008). Synergistic and additive actions of a psychosocial stressor and endotoxin challenge: circulating and brain cytokines, plasma corticosterone and behavioral changes in mice. Brain Behav. Immun. 22, 573-589.

Giovambattista, A., Chisari, A. N., Corro, L., Gaillard, R. C., and Spinedi, E. (2000).Metabolic,neuroendocrineand immune functions in basal conditions and during the acute-phase response to endotoxic shock in undernourished rats. Neuroimmunomodulation 7, 92-98.

Goehler, L. E., Busch, C. R., Tartaglia, N., Relton, J., Sisk, D., Maier, S. F., and Watkins, L. R. (1995). Blockade of cytokine induced conditioned taste aversion by subdiaphragmatic vagotomy: further evidence for vagal mediation of immune-brain communication. Neurosci. Lett. 185, 163-166.

Goehler, L. E., Erisir, A., and Gaykema, R. P. (2006). Neural-immune interface in the rat area postrema. Neuroscience 140, 1415-1434

Goehler, L. E., Relton, J. K., Dripps, D., Kiechle, R., Tartaglia, N., Maier, S. F., and Watkins, L. R. (1997). Vagal paragangliabind biotinylated interleukin-1 receptor antagonist: a possible mechanism for immune-to-brain communication. Brain Res. Bull. 43, 357-364.

Gold, R. M. (1970). Hypothalamic hyperphagia produced by parasagittal knife cuts. Physiol. Behav. 5, 23-25.

Goncalves, C. G., Ramos, E. J., Romanova, I.V., Suzuki, S., Chen, C., and Meguid, M. M. (2006). Omega-3 fatty acids improve appetite in cancer anorexia, but tumor resecting restores it. Surgery 139, 202-208.

Gosselin, D., and Rivest, S. (2008). MyD88 signaling in brain endothelial cells is essential for the neuronal activity and glucocorticoid release during systemic inflammation. Mol. Psychiatry 13, 480-497.

Grill,H.J.,Carmody,J.S.,Amanda Sadacca, L., Williams, D. L., and Kaplan, J. M. (2004). Attenuation of lipopolysaccharide anorexia by antagonism of caudal brain stem but not forebrain GLP-1-R. Am. J. Physiol. Regul. Integr. Comp. Physiol. 287, R1190-R1193.

Grill, H. J., and Smith, G. P. (1988). Cholecystokinin decreases sucrose intake in chronic decerebrate rats. Am. J. Physiol. 254, R853-R856.

Hart, B. L. (1988). Biological basis of the behavior of sick animals. Neurosci. Biobehav. Rev. 12, 123-137.

Hellerstein, M. K., Meydani, S. N., Meydani, M., Wu, K., and Dinarello, C. A. (1989). Interleukin-1-induced anorexia in the rat. Influence of prostaglandins. J. Clin. Invest. 84, 228-235.

Hermann, G. E., Emch, G. S., Tovar, C. A., and Rogers, R. C. (2001). C-Fos generation in the dorsal vagal complex after systemic endotoxin is not 
dependent on the vagus nerve. Am. J. Physiol. 280, R289-R299.

Hill, J. W., Williams, K. W., Ye, C., Luo, J., Balthasar, N., Coppari, R., Cowley, M. A., Cantley, L. C., Lowell, B. B., and Elmquist, J. K. (2008). Acute effects of leptin require PI3K signaling in hypothalamic proopiomelanocortin neurons in mice. J. Clin. Invest. 118, 1796-1805.

Holland, J. C., Rowland, J., and Plumb, M. (1977). Psychological aspects of anorexia in cancer patients. Cancer Res. 37, 2425-2428.

Huang, Q. H., Hruby, V. J., and Tatro, J. B. (1999). Role of central melanocortins in endotoxin-induced anorexia. Am. J. Physiol. 276, R864-R871.

Jatoi, A., Rowland, K., Loprinzi, C. L., Sloan, J. A., Dakhil, S. R., MacDonald, N., Gagnon, B., Novotny, P. J., Mailliard, J. A., Bushey, T. I., Nair, S., and Christensen, B. (2004). An eicosapentaenoic acid supplement versus megestrol acetate versus both for patients with cancer-associated wasting: a North Central Cancer Treatment Group and National Cancer Institute of Canada collaborative effort. J. Clin. Oncol. 22, 2469-2476.

Johnson, P. M., Vogt, S. K., Burney, M. W., and Muglia, L. J. (2002). COX-2 inhibition attenuates anorexia during systemic inflammation without impairing cytokine production. Am. J. Physiol. Endocrinol. Metab. 282, E650-E656.

Kapas, L., and Krueger, J. M. (1992). Tumor necrosis factor-beta induces sleep, fever, and anorexia. Am. J. Physiol. 263, R703-R707.

Kelley, A. E. (1999). Functional specificity of ventral striatal compartments in appetitive behaviors. Ann. N. Y. Acad. Sci. 877, 71-90.

Kelley,A.E., Andrzejewski, M.E., Baldwin, A. E., Hernandez, P. J., and Pratt, W.E. (2003). Glutamate-mediated plasticity in corticostriatal networks: role in adaptive motor learning. Ann. N. Y. Acad. Sci. 1003, 159-168.

Kent, S., Bluthe, R. M., Dantzer, R., Hardwick, A. J., Kelley, K. W., Rothwell, N.J., and Vannice, J.L. (1992). Different receptor mechanisms mediate the pyrogenic and behavioral effects of interleukin 1. Proc. Natl. Acad. Sci. U.S.A. 89, 9117-9120.

Kent, S., Bret-Dibat, J. L., Kelley, K. W., and Dantzer, R. (1996). Mechanisms of sickness-induced decreases in food-motivated behavior. Neurosci. Biobehav. Rev. 20, 171-175.

Kinzig, K. P., D’Alessio, D. A., and Seeley, R. J. (2002). The diverse roles of specific GLP-1 receptors in the control of food intake and the response to visceral illness. J. Neurosci. 22, 10470-10476.
Konsman, J. P., and Blomqvist, A. (2005). Forebrain patterns of c-Fos and FosB induction during cancer-associated anorexia-cachexia in rat. Eur. J. Neurosci. 21, 2752-2766.

Konsman, J. P., and Dantzer, R. (2001). How the immune and nervous systems interact during disease-associated anorexia. Nutrition 17, 664-668.

Konsman, J. P., Kelley, K., and Dantzer, R. (1999). Temporal and spatial relationships between lipopolysaccharide-induced expression of Fos, interleukin-1beta and inducible nitric oxide synthase in rat brain. Neuroscience 89, 535-548.

Konsman, J. P., Luheshi, G. N., Bluthe, R. M., and Dantzer, R. (2000). The vagus nerve mediates behavioural depression, but not fever, in response to peripheral immune signals; a functional anatomical analysis. Eur. J. Neurosci. 12, 4434-4446.

Konsman, J. P., Vigues, S., Mackerlova, L., Bristow, A., and Blomqvist, A. (2004). Rat brain vascular distribution of interleukin-1 type-1 receptor immunoreactivity: relationship to patterns of inducible cyclooxygenase expression by peripheral inflammatory stimuli. J. Comp. Neurol. 472, 113-129.

Koob, G. F. (1999). Corticotropin-releasing factor, norepinephrine, and stress. Biol. Psychiatry 46, 1167-1180.

Kristensen, P., Judge, M. E., Thim, L., Ribel, U., Christjansen, K. N., Wulff, B. S., Clausen, J. T., Jensen, P. B., Madsen, O. D., Vrang, N., Larsen, P. J., and Hastrup, S. (1998). Hypothalamic CART is a new anorectic peptide regulated by leptin. Nature 393, 72-76.

Lacroix, S., Vallieres, L., and Rivest, S. (1996). C-fos mRNA pattern and corticotropin-releasing factor neuronal activity throughout the brain of rats injected centrally with a prostaglandin of E2 type. J. Neuroimmunol. 70, 163-179.

Langhans, W., Harlacher, R., Balkowski, G., and Scharrer, E. (1990). Comparison of the effects of bacterial lipopolysaccharide and muramyl dipeptide on food intake. Physiol. Behav. 47, 805-813.

Langhans, W., Savoldelli, D., and Weingarten, S. (1993). Comparison of the feeding responses to bacterial lipopolysaccharide and interleukin-1 beta. Physiol. Behav. 53, 643-649.

Laviano, A., Meguid, M. M., and RossiFanelli, F. (2003). Cancer anorexia: clinical implications, pathogenesis, and therapeutic strategies. Lancet Oncol. 4, 686-694.

Laye, S., Bluthe, R.M., Kent, S., Combe, C., Medina, C., Parnet, P., Kelley, K., and Dantzer, R. (1995). Subdiaphragmatic vagotomy blocks induction of IL-1 beta mRNA in mice brain in response to peripheral LPS. Am. J. Physiol. 268, R1327-R1331.

Laye, S., Gheusi, G., Cremona, S., Combe, C., Kelley, K., Dantzer, R., and Parnet, P. (2000). Endogenous brain IL-1 mediates LPS-induced anorexia and hypothalamic cytokine expression. Am. J. Physiol. Regul. Integr. Comp. Physiol. 279, R93-R98.

Laye, S., Parnet, P., Goujon, E., and Dantzer, R. (1994). Peripheral administration of lipopolysaccharide induces the expression of cytokine transcripts in the brain and pituitary of mice. Brain Res. Mol. Brain Res. 27, 157-162.

Lennie, T. A. (1998). Relationship of body energy status to inflammationinduced anorexia and weight loss. Physiol. Behav. 64, 475-481.

Lin, H. C., Wan, F. J., Kang, B. H., Wu, C. C., and Tseng, C. J. (1999). Systemic administration of lipopolysaccharide induces release of nitric oxide and glutamate and c-fos expression in the nucleus tractus solitarii of rats. Hypertension 33, 1218-1224.

Liu, J., Garza, J.C., Truong, H.V., Henschel, J., Zhang, W., and Lu, X.Y. (2007). The melanocortinergic pathway is rapidly recruited by emotional stress and contributes to stress-induced anorexia and anxiety-like behavior. Endocrinology 148, 5531-5540

Lugarini, F., Hrupka, B. J., Schwartz, G. J., Plata-Salaman, C. R., and Langhans, W. (2002). A role for cyclooxygenase-2 in lipopolysaccharide-induced anorexia in rats. Am. J. Physiol. Regul. Integr. Comp. Physiol. 283, R862-R868.

Lugarini, F., Hrupka, B. J., Schwartz, G. J., Plata-Salaman, C. R., and Langhans, W. (2005). Acute and chronic administration of immunomodulators induces anorexia in Zucker rats. Physiol. Behav. 84, 165-173.

Lundholm, K., Gelin, J., Hyltander, A., Lonnroth, C., Sandstrom, R., Svaninger, G., Korner, U., Gulich, M., Karrefors, I., Norli, B., Hafstrom, L. O., Kewenter, J., Olbe, L., and Lundell, L. (1994).Anti-inflammatory treatment may prolong survival in undernourished patients with metastatic solid tumors. Cancer Res. 54, 5602-5606.

Luquet, S., Phillips, C. T., and Palmiter, R. D. (2007). NPY/AgRP neurons are not essential for feeding responses to glucoprivation. Peptides 28, 214-225.

Malick, A., Jakubowski, M., Elmquist, J. K., Saper, C. B., and Burstein, R. (2001). A neurohistochemical blueprint for pain-induced loss of appetite. Proc. Natl. Acad. Sci. U.S.A. 98 9930-9935.

Marks, D. L., Ling, N., and Cone, R. D. (2001). Role of the central melanocortin system in cachexia. Cancer Res. 61 , 1432-1438.
Marazziti, D., Betti, L., Giannaccini, G., Rossi, A., Masala, I., Baroni, S., Cassano, G. B., and Lucacchini, A. (2001). Distribution of [3H]GR65630 binding in human brain postmortem. Neuochem Res. 26, 187-190.

Marty, V., El Hachmane, M., and Amedee, T. (2008). Dual modulation of synaptic transmission in the nucleus tractus solitarius by prostaglandin $\mathrm{E} 2$ synthesized downstream of IL-1beta. Eur. J. Neurosci. 27, 3132-3150.

Mastronardi, C. A., Yu, W. H., Rettori, V., and McCann, S. (2000). Lipopolysaccharide-induced leptin release is not mediated by nitric oxide, but is blocked by dexamethasone. Neuroimmunomodulation 8, 91-97.

Matsumura, K., Watanabe, Y., and Onoe, H. (1995). Prostacyclin receptor in the brain and central terminals of the primary sensory neurons: an autoradiographic study using a stable prostacyclin analogue $[3 \mathrm{H}]$ iloprost. Neuroscience 65, 493-503.

Mattox, T. W. (2005). Treatment of unintentional weight loss in patients with cancer. Nutr. Clin. Pract. 20, 400-410

Mazzotta, P., and Jeney, C. M. (2009). Anorexia-cachexia syndrome: a systematic review of the role of dietary polyunsaturated Fatty acids in the management of symptoms, survival, and quality of life. J. Pain Symptom Manage. 37, 1069-1077.

Meguid, M. M., Yang, Z. J., Gleason, J. R., and Kubota, A. (1999). Differential feeding patterns induced by tumor growth and by TPN. Nutrition 15 , 555-562.

Merali, Z., Brennan, K., Brau, P., and Anisman, H. (2003). Dissociating anorexia and anhedonia elicited by interleukin-1beta: antidepressant and gender effects on responding for "free chow" and "earned" sucrose intake. Psychopharmacology (Berl.) $165,413-418$.

Mieda, M., Williams, S. C., Sinton, C. M., Richardson, J. A., Sakurai, T., and Yanagisawa, M. (2004). Orexin neurons function in an efferent pathway of a food-entrainable circadian oscillator in eliciting food-anticipatory activity and wakefulness. J. Neurosci. 24, 10493-10501.

Mingam, R., De Smedt, V., Amedee, T., Bluthe, R. M., Kelley, K. W., Dantzer, R., and Laye, S. (2008a). In vitro and in vivo evidence for a role of the P2X7 receptor in the release of IL-1 beta in the murine brain. Brain Behav. Immun. 22, 234-244.

Mingam, R., Moranis, A., Bluthe, R. M., De Smedt-Peyrusse, V., Kelley, K. W., Guesnet, P., Lavialle, M., Dantzer, R., and Laye, S. (2008b). Uncoupling of interleukin-6 from its signalling 
pathway by dietary $\mathrm{n}$-3-polyunsaturated fatty acid deprivation alters sickness behaviour in mice. Eur. $J$. Neurosci. 28, 1877-1886.

MohanKumar, S. M., MohanKumar, P. S., and Quadri, S. K. (1999). Lipopolysaccharide-induced changes in monoamines in specific areas of the brain: blockade by interleukin-1 receptor antagonist. Brain Res. 824, 232-237.

Morales, M., and Wang, S. D. (2002). Differential composition of 5-hydroxytryptamine3 receptors synthesized in the rat CNS and peripheral nervous system. J. Neurosci. 22, 6732-6741.

Nadjar, A., Bluthe, R. M., May, M. J., Dantzer, R., and Parnet, P. (2005). Inactivation of the cerebral NFkappaB pathway inhibits interleukin-1betainduced sickness behavior and c-Fos expression in various brain nuclei. Neuropsychopharmacology 30 , 1492-1499.

Neary, N. M., Small, C. J., Wren, A. M., Lee, J. L., Druce, M. R., Palmieri, C., Frost, G. S., Ghatei, M. A., Coombes, R. C., and Bloom, S. R. (2004). Ghrelin increases energy intake in cancer patients with impaired appetite: acute, randomized, placebo-controlled trial. J. Clin. Endocrinol. Metab. 89, 2832-2836.

Niijima,A. (1996). The afferent discharges from sensors for interleukin 1 beta in the hepatoportal system in the anesthetized rat. J. Auton. Nerv. Syst. 61, 287-291.

Nolan, Y., Connor, T. J., Kelly, J. P., and Leonard, B. E. (2000). Lipopolysaccharide administration produces time-dependent and regionspecific alterations in tryptophan and tyrosine hydroxylase activities in rat brain. J. Neural Transm. 107, 1393-1401.

Obreja, O., Rathee, P. K., Lips, K. S., Distler, C., and Kress, M. (2002). IL-1 beta potentiates heat-activated currents in rat sensory neurons: involvement of IL-1RI, tyrosine kinase, and protein kinase C. FASEB J. 16, 1497-1503.

Oka, T., Oka, K., Scammell, T. E., Lee, C., Kelly, J. F., Nantel, F., Elmquist, J. K., and Saper, C. B. (2000). Relationship of $\mathrm{EP}(1-4)$ prostaglandin receptors with rat hypothalamic cell groups involved in lipopolysaccharide fever responses. J. Comp. Neurol. 428, 20-32.

Park, S. M., Gaykema, R. P., and Goehler, L. E. (2008). How does immune challenge inhibit ingestion of palatable food? Evidence that systemic lipopolysaccharide treatment modulates key nodal points of feeding neurocircuitry. Brain Behav. Immun. 22, 1160-1172.

Patwardhan, A. M., Vela, J., Farugia, J., Vela, K., and Hargreaves, K. M. (2008). Trigeminal nociceptors express pros- taglandin receptors. J. Dent. Res. 87, 262-266.

Pecchi, E., Dallaporta, M., Thirion, S., Salvat, C., Berenbaum, F., Jean, A., and Troadec, J. D. (2006). Involvement of central microsomal prostaglandin $\mathrm{E}$ synthase-1 in IL-1beta-induced anorexia. Physiol. Genomics 25, 485-492.

Pierce, J. P., Natarajan, L., Caan, B. J., Parker, B. A., Greenberg, E. R., Flatt, S. W., Rock, C. L., Kealey, S., Al-Delaimy, W. K., Bardwell, W. A., Carlson, R. W., Emond, J. A., Faerber, S., Gold, E. B., Hajek, R. A., Hollenbach, K., Jones, L. A.,Karanja, N.,Madlensky,L.,Marshall, J., Newman, V. A., Ritenbaugh, C., Thomson, C. A., Wasserman, L., and Stefanick, M. L. (2007). Influence of a diet very high in vegetables, fruit, and fiber and low in fat on prognosis following treatment for breast cancer: the Women's Healthy Eating and Living (WHEL) randomized trial. JAMA 298, 289-298.

Pitchford, S., and Levine, J. D. (1991). Prostaglandins sensitize nociceptors in cell culture. Neurosci. Lett. 132, 105-108.

Plata-Salaman, C. R. (1996). Anorexia induced by activators of the signal transducer gp 130. Neuroreport 7 , 841-844.

Plata-Salaman, C. R., Ilyin, S. E., and Gayle, D. (1998). Brain cytokine mRNAs in anorectic rats bearing prostate adenocarcinoma tumor cells. Am. J. Physiol. Regul. Integr. Comp. Physiol. 44, R566-R573.

Plata-Salaman, C. R., Sonti, G., Borkoski, J.P., Wilson, C. D., and French-Mullen, J. M. B. (1996). Anorexia induced by chronic central administration of cytokines at estimated pathophysiological concentrations. Physiol. Behav. 60, 867-875.

Porter, M. H., Hrupka, B. J., Langhans, W., and Schwartz, G. J. (1998). Vagal and splanchnic afferents are not necessary for the anorexia produced by peripheral IL-1beta, LPS, and MDP. Am. J. Physiol. 275, R384-R389.

Reilly, S., and Trifunovic, R. (2000). Lateral parabrachial nucleus lesions in the rat: aversive and appetitive gustatory conditioning. Brain Res. Bull. 52, 269-278.

Reyes, T. M., and Sawchenko, P.E. (2002). Involvement of the arcuate nucleus of the hypothalamus in interleukin1 -induced anorexia. J. Neurosci. 22, 5091-5099.

Rinaman, L. (1999). Interoceptive stress activates glucagon-like peptide-1 neurons that project to the hypothalamus. Am. J. Physiol. 277, R582-R590.

Rivest, S. (1999). Activation of the nuclear factor kappa B (NF-kappaB) and cyclooxygenase-2 (COX-2) genes in cerebral blood vessels in response to systemic inflammation. Mol. Psychiatry 4, 500.

Rivest, S. (2003). Molecular insights on the cerebral innate immune system. Brain Behav. Immun. 17, 13-19.

Rivest, S., and Laflamme, N. (1995). Neuronal activity and neuropeptide gene transcription in the brains of immune-challenged rats. $J$. Neuroendocrinol. 7, 501-525.

Ruud, J., and Blomqvist, A. (2007). Identification of rat brainstem neuronal structures activated during cancer-induced anorexia. J. Comp. Neurol. 504, 275-286.

Sachot, C., Poole, S., and Luheshi, G. N. (2004). Circulating leptin mediates lipopolysaccharide-induced anorexia and fever in rats. J. Physiol. 561, 263-272.

Sagar, S. M., Price, K. J., Kasting, N. W., and Sharp, F. R. (1995). Anatomic patterns of Fos immunostaining in rat brain following systemic endotoxin administration. Brain Res. Bull. $36,381-392$.

Sakurai, T., Amemiya, A., Ishii, M., Matsuzaki, I., Chemelli, R. M., Tanaka, H., Williams, S. C., Richardson, J. A., Kozlowski, G. P., Wilson, S., Arch, J. R., Buckingham, R. E., Haynes, A. C., Carr S. A., Annan, R. S., McNulty, D. E., Liu, W.S., Terrett, J.A., Elshourbagy, N. A., Bergsma, D. J., and Yanagisawa, M (1998). Orexins and orexin receptors: a family of hypothalamic neuropeptides and $G$ protein-coupled receptors that regulate feeding behavior. Cell 92, 573-585.

Sanchez-Alavez, M., Klein, I., Brownell, S. E., Tabarean, I. V., Davis, C. N., Conti, B., and Bartfai, T. (2007). Night eating and obesity in the EP3R-deficient mouse. Proc. Natl. Acad. Sci. U.S.A. 104, 3009-3014

Sarraf, P., Frederich, R. C., Turner, E. M., $\mathrm{Ma}, \mathrm{G}$., Jaskowiak, N. T., Rivet, D. J. III, Flier, J. S., Lowell, B. B., Fraker, D. L., and Alexander, H. R. (1997). Multiple cytokines and acute inflammation raise mouse leptin levels: potential role in inflammatory anorexia. J. Exp. Med. 185, 171-175.

Scammell, T. E., Estabrooke, I. V., McCarthy, M. T., Chemelli, R. M., Yanagisawa, M., Miller, M. S., and Saper, C. B. (2000). Hypothalamic arousal regions are activated during modafinil-induced wakefulness. $J$. Neurosci. 20, 8620-8628.

Scarlett, J. M., Jobst, E. E., Enriori, P. J., Bowe, D. D., Batra, A. K., Grant, W. F., Cowley, M. A., and Marks, D. L. (2007). Regulation of central melanocortin signaling by interleukin-1 beta. Endocrinology 148, 4217-4225.

Schwartz, G. J. (2000). The role of gastrointestinal vagal afferents in the con- trol of food intake: current prospects. Nutrition 16, 866-873.

Schwartz, G. J., Plata-Salaman, C. R., and Langhans, W. (1997). Subdiaphragmatic vagal deafferentation fails to block feeding-suppressive effects of LPS and IL-1 beta in rats. Am. J. Physiol. 273, R1193-R1198.

Sclafani, A., Azzara, A. V., Touzani, K., Grigson, P. S., and Norgren, R. (2001). Parabrachial nucleus lesions block taste and attenuate flavor preference and aversion conditioning in rats. Behav. Neurosci. 115, 920-933.

Seeley, R. J., Drazen, D. L., and Clegg, D. J. (2004). The critical role of the melanocortin system in the control of energy balance. Annu. Rev. Nutr. 24, 133-149.

Sergeev, V. G., and Akmaev, I. G. (2000). Effects of vagotomy and bacterial lipopolysaccharide on food intake and expression of cyclooxygenase-2 mRNA in rat brain vessels. Bull. Exp. Biol. Med. 129, 553-555.

Sergeyev, V., Broberger, C., and Hokfelt, T. (2001). Effect of LPS administration on the expression of POMC, NPY, galanin, CART and MCH mRNAs in the rat hypothalamus. Brain Res. Mol. Brain Res. 90, 93-100.

Seruga, B., Zhang, H., Bernstein, L. J., and Tannock, I. F. (2008). Cytokines and their relationship to the symptoms and outcome of cancer. Nat. Rev. Cancer 8, 887-899.

Snitsarev, V., Whiteis, C. A., Chapleau, M. W., and Abboud, F. M. (2007). Mechano- and chemosensitivity of rat nodose neurones - selective excitatory effects of prostacyclin.J. Physiol. (Lond.) 582, 177-194.

Sonti, G., Ilyin, S. E., and Plata-Salaman, C. R. (1996). Anorexia induced by cytokine interactions at pathophysiological concentrations. Am. J. Physiol. 270, R1394-R1402.

Spathis, A., Dhillan, R., Booden, D., Forbes, K., Vrotsou, K., and Fife, K. (2009). Modafinil for the treatment of fatigue in lung cancer: a pilot study. Palliat. Med. 23, 325-331.

Spencer, S. J., Mouihate, A., Galic, M. A., Ellis, S. L., and Pittman, Q. J. (2007). Neonatal immune challenge does not affect body weight regulation in rats. Am. J. Physiol. Regul. Integr. Comp. Physiol. 293, R581-R589.

Strasser, F., Luftner, D., Possinger, K., Ernst, G., Ruhstaller, T., Meissner, W., Ko, Y. D., Schnelle, M., Reif, M., and Cerny, T. (2006). Comparison of orally administered cannabis extract and delta-9-tetrahydrocannabinol in treating patients with cancer-related anorexia-cachexia syndrome: a multicenter, phase III, randomized, double-blind, placebo-controlled clinical trial from the Cannabis-In- 
Cachexia-Study-Group. J. Clin. Oncol. 24, 3394-3400.

Takao, T., Tracey, D. E., Mitchell, W. M., and De Souza, E. B. (1990). Interleukin-1 receptors in mouse brain: characterization and neuronal localization. Endocrinology 127, 3070-3078.

Takeda, M., Kitagawa, J., Takahashi, M., and Matsumoto, S. (2008). Activation of interleukin-1beta receptor suppresses the voltage-gated potassium currents in the small-diameter trigeminal ganglion neurons following peripheral inflammation. Pain 139, 594-602.

Tazi, A., Dantzer, R., Crestani, F., and Le Moal, M. (1988). Interleukin-1 induces conditioned taste aversion in rats: a possible explanation for its pituitary-adrenal stimulating activity. Brain Res. 473, 369-371.

Tecott, L. H., Maricq, A. V., and Julius, D. (1993). Nervous system distribution of the serotonin 5-HT3 receptor mRNA. Proc. Natl. Acad. Sci. USA 90, 1420-1434.

Tisdale, M. J. (2006). Clinical anticachexia treatments. Nutr. Clin. Pract. 21, 168-174.

Tisdale,M.J.(2009).Mechanisms of cancer cachexia. Physiol. Rev. 89, 381-410.

Tkacs, N. C., and Li, J. (1999). Immune stimulation induces Fos expression in brainstem amygdala afferents. Brain Res. Bull. 48, 223-231.

Turrin, N. P., Gayle, D., Ilyin, S. E., Flynn, M. C., Langhans, W., Schwartz, G. J., and Plata-Salaman, C. R. (2001). Proinflammatory and anti-inflammatory cytokine mRNA induction in the periphery and brain following intraperitoneal administration of bacterial lipopolysaccharide. Brain Res. Bull. 54, 443-453.

Uehara, A., Sekiya, C., Takasugi,Y., Namiki, M., and Arimura, A. (1989). Anorexia induced by interleukin 1: involvement of corticotropin-releasing factor. Am. J. Physiol. 257, R613-R617. van Dam, A. M., Bauer, J., Tilders, F. J., and Berkenbosch, F. (1995). Endotoxininduced appearance of immunoreactive interleukin-1 beta in ramified microglia in rat brain: a light and electron microscopic study. Neuroscience 65, 815-826.

van Dam, A. M., Brouns, M., Louisse, S., and Berkenbosch, F. (1992). Appearance of interleukin-1 in macrophages and in ramified microglia in the brain of endotoxin-treated rats: a pathway for the induction of non-specific symptoms of sickness? Brain Res. 588, 291-296.

Varma, M., Chai, J. K., Meguid, M. M., and Yang, Z. J. (2001). Gender differences in tumor-induced anorectic feeding pattern in Fischer-344 rats. Physiol. Behav. 74, 29-35.

von Meyenburg, C., Langhans, W., and Hrupka, B. J. (2003a). Evidence for a role of the 5-HT2C receptor in central lipopolysaccharide-, interleukin-1 beta-, and leptin-induced anorexia. Pharmacol. Biochem. Behav. 74, 1025-1031.

von Meyenburg, C., Langhans, W., and Hrupka, B. J. (2003b). Evidence that the anorexia induced by lipopolysaccharide is mediated by the $5-\mathrm{HT} 2 \mathrm{C}$ receptor. Pharmacol. Biochem. Behav. 74, 505-512.

Wan, W., Janz, L., Vriend, C. Y., Sorensen, C. M., Greenberg, A. H., and Nance, D.M. (1993). Differential induction of c-Fos immunoreactivity in hypothalamus and brain stem nuclei following central and peripheral administration of endotoxin. Brain Res. Bull. 32, 581-587.

Weiland, T.J.,Anthony-Harvey-Beavis, D., Voudouris, N. J., and Kent, S. (2006). Metabotropic glutamate receptors mediate lipopolysaccharide-induced fever and sickness behavior. Brain Behav. Immun. 20, 233-245.

Weinberg, E. D. (1984). Iron withholding: a defense against infection and neoplasia. Physiol. Rev. 64, 65-102.
Weingarten, S., Senn, M., and Langhans, W. (1993). Does a learned taste aversion contribute to the anorectic effect of bacterial lipopolysaccharide? Physiol. Behav. 54, 961-966.

Wieczorek, M., Swiergiel, A. H. Pournajafi-Nazarloo, H., and Dunn A. J. (2005). Physiological and behavioral responses to interleukin-1beta and LPS in vagotomized mice. Physiol. Behav. 85, 500-511.

Wigmore, S. J., Barber, M. D., Ross, J. A., Tisdale, M. J., and Fearon, K. C. (2000). Effect of oral eicosapentaenoic acid on weight loss in patients with pancreatic cancer. Nutr. Cancer 36, 177-184.

Wing, E. J., and Young, J. B. (1980). Acute starvation protects mice against Listeria monocytogenes. Infect. Immun. 28, 771-776.

Wisse, B. E., Frayo, R. S., Schwartz, M. W., and Cummings, D. E. (2001) Reversal of cancer anorexia by blockade of central melanocortin receptors in rats. Endocrinology 142 3292-3301.

Wisse, B. E., Ogimoto, K., Tang, J., Harris, M. K. Jr., Raines, E. W., and Schwartz M. W. (2007). Evidence that lipopolysaccharide-induced anorexia depends upon central, rather than peripheral, inflammatory signals. Endocrinology 148, 5230-5237.

Wynne, K., Giannitsopoulou, K., Small, C. J., Patterson, M., Frost, G., Ghatei, M. A., Brown, E. A., Bloom, S. R., and Choi, P. (2005). Subcutaneous ghrelin enhances acute food intake in malnourished patients who receive maintenance peritoneal dialysis: a randomized, placebo-controlled trial. J. Am. Soc. Nephrol. 16, 2111-2118.

Xu, Y., Jones, J. E., Kohno, D., Williams, K. W., Lee, C. E., Choi, M. J., Anderson, J. G., Heisler, L. K., Zigman, J. M., Lowell, B. B., and Elmquist, J. K. (2008). 5-HT2CRs expressed by proopiomelanocortin neurons regulate energy homeostasis. Neuron 60 582-589.

Yao, J. H., Ye, S. M., Burgess, W., Zachary, J. F., Kelley, K. W., and Johnson, R. W. (1999). Mice deficient in interleukin-1beta converting enzyme resist anorexia induced by central lipopolysaccharide. Am. J. Physiol. 277, R1435-R1443.

Yirmiya, R. (1996). Endotoxin produces a depressive-like episode in rats. Brain Res. 711, 163-174.

Zhang, J., and Rivest, S. (1999). Distribution, regulation and colocalization of the genes encoding the EP2- and EP4-PGE2 receptors in the rat brain and neuronal responses to systemic inflammation. Eur. J. Neurosci. 11, 2651-2668.

Zhang, S., Folsom,A. R., Sellers, T.A., Kushi, L.H., and Potter,J.D.(1995). Betterbreast cancer survival for postmenopausal women who are less overweight and eat less fat. The Iowa Women's Health Study. Cancer 76, 275-283.

Conflict of Interest Statement: The authors declare that the research was conducted in the absence of any commercial or financial relationships that could be construed as a potential conflict of interest.

Received: 27 October 2009; paper pending published: 18 November 2009; accepted: 16 December 2009; published online: 08 January 2010.

Citation: Gautron L and Layé S (2010) Neurobiology of inflammation-associated anorexia. Front. Neurosci. 3:59. doi 10.3389/neuro.23.003.2009

This article was submitted to Frontiers in Neuropharmacology, a specialty of Frontiers in Neuroscience.

Copyright $(2010$ Gautron and Layé. This is an open-access article subject to an exclusive license agreement between the authors and the Frontiers Research Foundation, which permits unrestricted use, distribution, and reproduction in any medium, provided the original authors and source are credited. 